\title{
Ethnologies
}

Jump Jim Crow: Lost Plays, Lyrics, and Street Prose of the First Atlantic Popular Culture. By W.T. Lhamon, Jr. (Cambridge \&

London, Harvard University Press, 2003. Pp.xi + 459, illustrations, index, ISBN: 0-674-01062-0)

\section{Jordan Mitchell}

Volume 31, numéro 1, 2009

Passages

URI : https://id.erudit.org/iderudit/038511ar

DOI : https://doi.org/10.7202/038511ar

Aller au sommaire du numéro

Éditeur(s)

Association Canadienne d'Ethnologie et de Folklore

ISSN

1481-5974 (imprimé)

1708-0401 (numérique)

Découvrir la revue

Citer ce compte rendu

Mitchell, J. (2009). Compte rendu de [Jump Jim Crow: Lost Plays, Lyrics, and

Street Prose of the First Atlantic Popular Culture. By W.T. Lhamon, Jr.

(Cambridge \& London, Harvard University Press, 2003. Pp.xi + 459,

illustrations, index, ISBN: 0-674-01062-0)]. Ethnologies, 31(1), 268-271.

https://doi.org/10.7202/038511ar 
sont ainsi autant d'invitations à considérer le don comme une pratique qui, par l'échange qu'elle implique, ouvre un espace social qui conduit à la fois à reconsidérer les catégorisations déjà établies et à mieux apprécier la pluralité du monde social. La troisième partie, la plus actuelle et la plus réflexive, présente trois enjeux contemporains dans le monde que l'auteure qualifie de "postmoderne " et qui chacun, de manière parfois surprenante, nous ramènent à la question du don : le rapport entre savoir et technologie avec le développement du virtuel (Chapitre 10), où l'échange de données, d'informations, d'images dans le cyberespace contribue, à l'instar du don, à la création ou au maintien de lien sociaux ; les enjeux de la propriété culturelle et du patrimoine en contexte de mondialisation (Chapitre 11) ; qui invite à réfléchir aux rapports entre la dimension juridique de la propriété culturelle et l'effectivité sociale des pratiques impliquées dans les politiques de sauvegarde et de préservation; et l'éthique de la représentation des "Autres" dans le travail anthropologique (Chapitre 12) que l'auteure traduit en termes d'échange, de don et de contre-don entre l'anthropologue et son terrain, et l'ensemble d'obligations que cela implique, l'un envers l'autre.

\section{Référence}

Elden, Stuart. 2008. "The Exchange Economy of Peer Review». Environment and Planning D. Society and Space 26 (6): 951-953.

Van Troi Tran

Université Laval

Jump Jim Crow: Lost Plays, Lyrics, and Street Prose of the First Atlantic Popular Culture. By W.T. Lhamon, Jr. (Cambridge \& London, Havard University Press, 2003. Pp.xi + 459, illustratlons, index, ISBN: 0-67401062-0)

In this book Lhamon analyzes the career of Thomas Dartmouth Rice, the famous or infamous "Jim Crow." Rice's career spanned the period from the early 1830 s until his death in 1860 . In the nearly two centuries since Rice first appeared, Jim Crow has come to signify American racism. However, Lhamon provides convincing evidence that Rice was other than a white man making fun of black people for white entertainment. Though at times Lhamon seems to be conflating blackface with real blackness, he admits that blackface was racist by nature and not a portrayal of authentic blackness. 
Arguably his most famous role, "Jim Crow" was a vehicle for Rice's efforts to "change the joke and slip the yoke" (ix). The white massas became the real butt of the joke and turned some of the attention away from the grotesquerie of blackness that was blackface. In one of his best written statements Lhamon says:

Imitating perceived blackness is arguably the central metaphor for what it is to be an American, even to be a citizen of that wider Atlantic world that suffers still from having installed, defended, and opposed its peculiar history of slavery (1).

Lhamon claims that Rice's ability to satisfy white desire for blackness was at the heart of his popularity. Rice's blackface appeared when blackness first became popular in America.

Lhamon examines the role of blackface as an entertainment form that attempted to integrate the struggle of lower class Whites with Blacks in a backlash against the oppression of the middle and upper classes. Although not quite integration, this type of performance stood against the segregationist values of elites like former President John Quincy Adams. Segregation was not the norm among lower classes, where crossracial pairings were common. The frightening spectre of this "demotic brotherhood dressed in black" caused people with power to oppose and eventually ban Jim Crow (8). By the mid-nineteenth century they had managed to twist blackface into the more overtly racist minstrel show.

For most of Rice's career, Jim Crow remained a counterforce to the hegemonic usage of Shakespeare's Othello. Later on his career, Rice's play Otello turned the message of Othello on its head. While contemporary performances of Othello played up Othello's wretchedness as a message against interracial marriage, Rice's Otello survives the play and sires a literally half black, half white baby. Lhamon claims the baby's appearance reflected both the desire of Whites for blackness as well as the desire of Whites to keep their identities separate from those of Blacks. Lhamon ends his book with the statement "Of all the footprints [Rice] left along Atlantic shores, the deepest is that Otello's and Desdemona's baby looks like us" (92). Lhamon may be on to something in our cultural ideas of the separateness of racial identities.

The idea of "lateral sufficiency" is central to this book. Lhamon defines this as the idea that it is better stay poor, clever and honest than to rise to the pretentious heights of the upper and middle classes. In 
Rice's plays, rich Whites are the villains and their interactions with victorious "Black" characters are richly coded in a way that perplexes middle and upper class readers. Lateral sufficiency is juxtaposed with the dominant culture's notion that "everybody wants to be like us" (19). Even today, characters rarely move beyond their station in life for longer than the length of one television episode.

While I question what the meaning of the victories of Black characters may have had to blackface audiences, it is certain that these plays are not written for massas. Lhamon states "although commonly referring to white bosses as 'massa,' not one of Rice's characters is ultimately confined, defeated or mastered" (27). In Jim Crow plays and songs, massa ends up chopping firewood in hell. By enacting stereotypical ideas of Blacks while portraying "blackness" triumphantly, it seems Rice both "saps and sets stereotypes" (2). While Rice discusses the role of blackface in the U.S. and England, it would be interesting to know if Rice ever did any productions ir. Canada and what effect his performance might have had on racial consciousness here.

I have had difficulty accepting some of Lhamon's arguments. At times Lhamon speaks for Rice's audience without providing much data on audience perception beyond a few editorials by critics. He seems to assume that white and black audiences fel: unified by Rice's plays based on his own, nonetheless insightful, reading of the texts. While there may have been more brotherhood than enmity towards Blacks among Rice's audiences, the meaning of "Jim Crow" to contemporaries remains unproven. Furthermore, Lhamon says that Rice's tactics of promoting Jim Crow were like the chant "black is beautiful" (35). The unspoken difference is, of course, that Rice's Jim Crow is not really black, so real blackness is not what is being promoted. Lastly, Lhamon claims that Rice was an abolitionist but he does not provide much evidence. While there are abolitionist statements in some of Rice's plays, it is unclear whether we should take them at face value. Was he simply playing the fool or was he really advocating what he said in character. However, it is interesting to note that Blacks attended Rice's shows; there is evidence at least one of them did so of his own free will.

In some instances Lhamon seems to contradict himself. He says, "Neither in the skits nor in reality did black subjects stand still and let themselves be spoken through" (14). I am still convinced that this is exactly what is happening in these skits. How can the appropriation of blackness by white actors and usually white writers be anything other 
then the act of Whites speaking through a thin coat of blackness? Lhamon makes two statements that seem to contradict his method of analyzing the play's texts and deducing what the play's effect on the audience must have been. He says " 'you can't hear the yah! Yah!' of Jim Crow's underclass scoffing" (25). In another instance he says that Rice was aware that symbols mean different things to different audiences. Given these two statements by Lhamon, how can we know Rice's audiences without hearing from them?

While Lhamon states his awareness of the fact that Rice's plays were racist, this book lacks a discussion of why the "grotesquerie" of blackness was an effective tool against rich Whites. When Lhamon quotes Rice as saying he hoped black dandyism would "discourage the original in whites" the statement seems to speak about abhorrence of Blacks (23). As Lhamon says "Grotesquerie of Blacks is his vehicle not his target" (23). I wonder if these performances reinforced the perceived grotesquerie of the "vehicle".

Lhamon boldly reexamines and challenges popular ideas about a chapter of Atlantic history that others would rather ignore. While the effect that Rice had on the minds of his audience remains unproven, Lhamon is to be commended for pointing out that Rice's plays offered the first positive portrayals of Blacks in America's written history. This came at a time when other plays painted Blacks as pitiful and wretched. Most importantly, this book provides valuable insights into the early history of American white fascination with blackness, something that is at least as strong today as it ever was.

Jordan Mitchell Memorial University of Newfoundland $\mathcal{G}$ Labrador

Alaska's Women Pilots: Contemporary Portraits. By Jenifer Lee Fratzke. (Utah State University Press, 2004. Pp. xiv + 231, ill., photos, ISBN 0-87421583-8)

Flying has been - and still is - seen as a male profession. Yet there is every reason why women should make equally good pilots. In fact, it could be argued that women in general would make better pilots, tending to err on the side of caution rather than recklessness. Fratzke has added to the growing literature showing that women deserve their rightful 